\title{
Erratum
}

\section{How Useful is the Cumul des Mandats for Being Re-elected? Empirical Evidence from the 1997 French Legislative Elections}

Martial Foucault

French Politics (2007) 5, 119. doi:10.1057/palgrave.fp.8200117

Correction to: French Politics (2006) 4.3, 292-311.

doi:10.1057/palgrave.fp. 8200106

The equation appearing on page 295 of the article featured an incorrect symbol:

$$
C(X) \pi \sum_{i=1}^{n} C\left(X_{i}\right)
$$

The equation should have appeared as follows:

$$
C(X)<\sum_{i=1}^{n} C\left(X_{i}\right)
$$

